\title{
Spatially explicit fate factors of phosphorous emissions to freshwater at the global scale
}

\author{
Roel J. K. Helmes • Mark A. J. Huijbregts • \\ Andrew D. Henderson • Olivier Jolliet
}

Received: 8 June 2011 / Accepted: 11 January 2012 /Published online: 2 February 2012

(C) The Author(s) 2012. This article is published with open access at Springerlink.com

\begin{abstract}
Purpose The location of a phosphorus emission can strongly affect its expected fate in freshwater. To date, in Life Cycle Assessment (LCA), fate factors for phosphorus emissions have been derived for continents or large countries and had limited spatial resolution. These fate factors do not account sufficiently for local variations and are not applicable globally. In this paper, fate factors for freshwater eutrophication are derived for phosphorus emissions to freshwater on a global scale with a half-degree resolution.

Methods For this purpose, a new global fate model for phosphorus has been developed on a half-degree resolution. The removal processes taken into account are grid-specific advection, phosphorus retention and water use. Aggregated fate factors based on archetypes and on administrative units are presented.

Results and discussion The derived fate factors represent the persistence of phosphorus in the freshwater environment. The
\end{abstract}

Responsible editor: Ralph K. Rosenbaum

Electronic supplementary material The online version of this article (doi:10.1007/s11367-012-0382-2) contains supplementary material, which is available to authorized users.

R. J. K. Helmes • M. A. J. Huijbregts

Department of Environmental Sciences, FNWI,

Radboud Universiteit Nijmegen,

Heijendaalseweg 135,

6525 AJ Nijmegen, The Netherlands

R. J. K. Helmes $\cdot$ A. D. Henderson $(\triangle) \cdot$ O. Jolliet

Department of Environmental Health Sciences,

School of Public Health, University of Michigan,

1415 Washington Heights,

Ann Arbor, MI 48109, USA

e-mail: henderad@umich.edu typical fate factor of phosphorus emissions to freshwater is 10 days and can vary more than 2 orders of magnitude among the grid cells (the 5 th and 95 th percentile are 0.8 and 310 days, respectively). Advection is the dominant removal process of phosphorus in freshwater (67.5\%), followed by retention $(27.6 \%)$ and water use $(4.9 \%)$.

Conclusions The results demonstrate inclusion of information on the location of phosphorus emissions to freshwater can improve the comparative power of the fate factor implementation in LCAs. The fate factors enable consistent assessment and comparison of freshwater eutrophication impacts at different locations across the globe.

Keywords Differentiation · Fate factors · Freshwater eutrophication · Life cycle assessment · Nutrients . Phosphorus · Spatial

\section{Introduction}

Freshwater eutrophication is the process of increasing algal growth and changing species abundance and diversity in surface water due to an enrichment of surface water with nutrients (Smith 2003). Growth of phytoplankton can lead to reduced light penetration, increased incidence of surface algal scums and deoxygenation, causing fish kills and other effects on ecosystems and humans (Withers and Jarvie 2008). Eutrophication has been a global concern for some time (OECD 1982; NRC 1992), and is likely to increase because of growing population and concomitant needs for increased food supply, agricultural land, and fertilizer use (Tilman et al. 2001; MEA 2005). Indeed, increased use of phosphorus fertilizer, relative to the pre-industrial era, has 
already increased the global river export of phosphorus from 8 to $22 \mathrm{Tg} /$ year (Bennet et al. 2001).

Phosphorus is often the primary limiting nutrient for primary production, and thus eutrophication, in freshwater (Schindler 1977; Carpenter et al. 1998). However, it has been known since the 1960s that nitrogen may also be a limiting nutrient (Schindler 2006). In particular, recent work suggests that nitrogen and even iron may be co-limiting over time scales relevant to biological cycles, though it is still likely that phosphorus may be the controlling limiting nutrient over scales of multiple years (Sterner 2008). Empirical evidence from the United States (Schindler 2006) corroborates this generalization. Nonetheless, the relationships between phosphorus supply, ambient phosphorus concentration in the water column and ecological response are complex: the movement of phosphorus through water bodies, related to their capacity to assimilate phosphorus, varies spatially and temporally (Withers and Jarvie 2008).

Freshwater eutrophication is commonly taken into account as an impact category in Life Cycle Assessment (LCA). In the Life Cycle Impact Assessment (LCIA) phase of LCA, inventory emission data are translated into potential environmental impacts via characterization factors (Pennington et al. 2004), which express the fate and effect of these stressors. In the LCIA framework, the fate factor (FF) represents the overall persistence of a substance, in this case phosphorus, in the environment, including removal via advection, partitioning and water use. Ecological effect factors (EF) express the relationship between the ecological damage (e.g., species richness changes due to eutrophication) and the mass change of the pollutant of interest in water or another environmental compartment (Rosenbaum et al. 2007).

In the past, several LCA methods have incorporated spatial differentiation in their fate factors (Potting and Hauschild 2006). It has been demonstrated that exclusion of spatial differentiation may diminish the relevance of an impact assessment (Potting and Blok 1994, 1995). Conversely, inclusion of spatial differentiation may enhance an assessment by identifying locations where emissions are more or less impactful. For example, acidification impact factors in Europe may vary by 3 orders of magnitude (Potting et al. 1998). Eutrophication potentials were found to vary by up to 1.5 orders of magnitude and acidification potentials varied up to 3.5 orders of magnitude in a country-level spatial model of nitrogen and sulfur air emissions in Europe (Huijbregts and Seppälä 2000). Finally, a spatially resolved model for emissions of organic chemicals in North America found a variation in human health impacts of up to 8 orders of magnitude (Humbert et al. 2009).

For nutrients in freshwater, the methods EDIP2003 (Potting et al. 2005) and ReCiPe (Struijs et al. 2009) included the nutrient fate model CARMEN (Beusen et al.
1995), which operates at the European scale on a country level. In the LCA method TRACI (Norris 2003), US state-level differentiated fate factors were derived for $\mathrm{N}$ emissions to water using data from Fekete et al. (2000) and Vörösmarty et al. (2000a b), while P emissions to water were not spatially differentiated. The Canadian LUCAS method draws from EDIP2003 and TRACI for eutrophication, using an adapted CARMEN model for phosphorus fate (Toffoleto et al. 2006). To date, most LCA methods for freshwater eutrophication have focused on one continent and operate on the relatively coarse resolution of countries or states. However, fate factors for Europe and Northern America are not comparable and cannot be used in a multi-continent assessment. Fate factors for phosphorus for other continents are not available, yet inventory data for a product or service may easily include inputs from several countries or continents, forcing an LCIA practioner to use characterization factors outside of the geographical context for which they were developed.

The goal of this study is to derive spatially explicit fate factors for phosphorus emissions to freshwater on a worldwide scale. For the derivation of the fate factors, a new global fate model for phosphorus has been developed. The importance of the modeled phosphorus removal processes for the fate factors is demonstrated and the most important assumptions and uncertainties are discussed.

\section{Methods}

\subsection{Framework}

The LCIA approach to characterizing an emission involves coupling an emission's fate in the environment (fate factor $[\mathrm{FF}]$ ) with the effect (effect factor $[\mathrm{EF}]$ ) of that substance (see, e.g., Rosenbaum et al. 2007). The fate factor $\left(\mathrm{FF}_{i, j}\right.$, day) represents the change in mass in a receiving compartment cell $j\left(\Delta M_{i, j}, \mathrm{~kg}\right)$ due to an emission in compartment cell $i\left(S_{i}, \mathrm{~kg}\right.$ day $\left.^{-1}\right)$, i.e.,

$\mathrm{FF}_{i, j}=\Delta M_{i, j} / S_{i}$

In the case of eutrophication, the effect factor can be expressed as the change in potentially disappeared fraction ( $\triangle \mathrm{PDF}$, dimensionless) of species in receiving compartment $j$ over the volume $\left(V_{j}, \mathrm{~m}^{3}\right)$ per unit increase in mass of phosphorus (Payet 2006; Struijs et al. 2011):

$$
\begin{aligned}
\mathrm{EF}_{j} & =\Delta \mathrm{PDF}_{j} \cdot V_{j} / \Delta M_{j}=\Delta \mathrm{PDF}_{j} \cdot V_{j} / \Delta C_{j} \cdot V_{j} \\
& =\Delta \mathrm{PDF}_{j} / \Delta C_{j}
\end{aligned}
$$

Although models can have spatially differentiated effect factors, this discussion assumes constant effect factors, i.e., 
$\mathrm{EF}_{j}=\mathrm{EF}$. It follows that the individual fate factors $\left(\mathrm{FF}_{i, j}\right.$, days $)$ can be summed, resulting in the cumulative fate factor of an emission to freshwater in cell $i\left(\mathrm{FF}_{i}\right.$, days), which is related to the fate in cell $i$ and all receiving cells $j$ downstream. Including this summation and coupling the FF and EF, the overall eutrophication characterization factor is expressed in Eq. 3 .

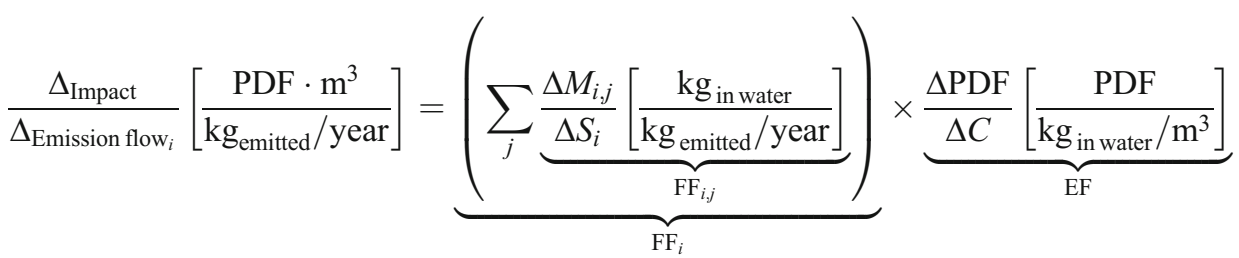

This equation presents the general LCIA approach to characterization, providing context for the following discussion, which focuses on the development of a spatially differentiated fate factor for phosphorus. In the LCIA framework, if the effect factor is constant, a larger fate factor means a larger $\mathrm{CF}$ and thus a higher potential environmental impact. A larger fate factor means a higher cumulative persistence in the context of freshwater eutrophication, implying phosphorus will be available longer for algae growth and the subsequent cascade of effects caused by that growth. The interaction between algae blooms and cumulative persistence of phosphorus has not been modeled. This is in keeping with current LCIA practice, in which the effects captured by the effect factor are separate from the fate factor. Biomass growth is included in the removal rate of phosphorus via retention and settling.

\subsection{Model structure}

Fate factors of phosphorus emissions to freshwater were derived for a $0.5^{\circ} \times 0.5^{\circ}$ grid covering the globe. At the global scale, advection, retention and water use were identified as the most important processes affecting phosphorus fate in freshwater (Bennet et al. 2001; Harrison et al. 2005; Mayorga et al. 2010; Seitzinger et al. 2005). In each grid cell, each of these processes results in phosphorus removal and is modeled by a single rate constant, as shown by the $k$ arrows in Fig. 1. The grid cells are connected through the

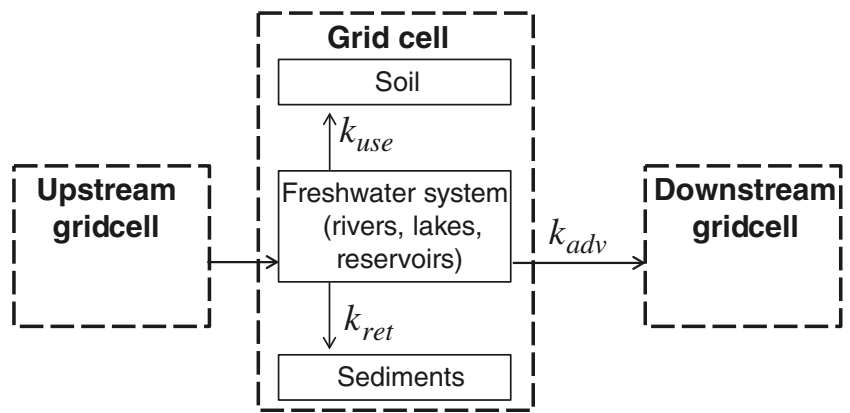

Fig. 1 Spatial relations between the model grid cells and their environmental compartments freshwater system, with advection transporting water and phosphorus $\left(k_{\mathrm{adv}}\right.$ in Fig. 1) to downstream grid cells. Phosphorus is also cycled between the freshwater system and the sediment, via the uptake and release of phosphorus by particles or organisms, resulting in a net removal and retention $\left(k_{\text {ret }}\right)$ in the grid cells. Furthermore, both water and phosphorus are transferred to agricultural soil via irrigation, and only a share of that phosphorus is returned to the freshwater system by runoff. As a result, irrigation leads to a net removal of phosphorus from the freshwater environment $\left(k_{\text {use }}\right)$. For the grid cell delineation and connectivity, the $0.5^{\circ} \times 0.5^{\circ}$ gridded river network from Vörösmarty et al. was used $(2000 \mathrm{a}, \mathrm{b})$. The topology of their river network is derived from a digital elevation model and aligned with independent river routing data. Grid specific discharge and runoff data are created by reconciling empirical discharge data with the discharge calculated in the water balance model of Fekete et al. (2002).

As shown in Eq. 3, the cumulative fate factor $\left(\mathrm{FF}_{i}\right)$ for an emission in cell $i$ is the sum of the fate factors for the individual cell of emission and of all downstream receptor grid cells $\left(\mathrm{FF}_{i, j}\right)$. The individual fate factors are the product of the persistence of phosphorus in freshwater in receptor cell $j\left(\tau_{j}\right.$, days) and of the fraction of phosphorus transported from the source grid cell $i$ to receptor grid cell $j\left(f_{i, j}\right.$, dimensionless):

$\mathrm{FF}_{i}=\sum_{j} \mathrm{FF}_{i, j}=\sum_{j} f_{i, j} \cdot \tau_{j}$

The persistence in grid cell $j$ is the inverse of the sum of its removal rates $\left(k_{\mathrm{adv}, j}, k_{\mathrm{ret}, j}, k_{\mathrm{use}, j}\right.$, day $\left.{ }^{-1}\right)$, as presented in Eq. 5, in which $k_{\mathrm{adv}, j}\left(\mathrm{day}^{-1}\right)$ represents the removal rate of phosphorus by the advective flow of water out of the grid cell, $k_{\mathrm{ret}, j}\left(\right.$ day $\left.^{-1}\right)$ represents the phosphorus retention rate, and $k_{\text {use, } j}\left(\right.$ day $\left.^{-1}\right)$ is the removal rate due to water use.

$\tau_{j}=\frac{1}{k_{\mathrm{adv}, j}+k_{\mathrm{ret}, j}+k_{\mathrm{use}, j}}$

The fraction of an emission in grid cell $i$ that reaches receptor grid cell $j, f_{i, j}$, also depends on the same removal rates and is the product of all fractions of phosphorus transported from one grid cell to the next, from the source to 
receptor grid cells (with $l$ indicating the grid cell of focus between the source cell $i$ to the first cell upstream of the receptor cell $j$, and $f_{i, i}=1$ ):

$f_{i, j}=\prod_{l=i}^{j-1} \frac{k_{\mathrm{adv}, l}}{k_{\mathrm{adv}, l}+k_{\mathrm{ret}, l}+k_{\mathrm{use}, l}}$

The following sections discuss the components of Eqs. 5 and 6 .

\subsubsection{Advection}

The river network of Vörösmarty et al. (2000a, b) indicates the downstream grid cell corresponding to each cell in the global model. The rate of phosphorus removed by advection from a grid cell is equal to the rate of water removal in that cell. This value is the ratio between its discharge $\left(Q_{i}, \mathrm{~km}^{3}\right.$ day $\left.^{-1}\right)$ (Fekete et al. 2002) and the total water volume in the grid cell $\left(V_{\text {tot }, i}, \mathrm{~km}^{3}\right)$, which is the sum of the volumes of lakes, reservoirs and rivers:

$k_{\mathrm{adv}, i}=\frac{Q_{i}}{V_{\mathrm{tot}, i}}$

The river volume was calculated from the river width, depth and length. River width and depth were calculated by empirical relationships from Wollheim et al. (2006), while length was determined with the relation between watershed surface area and river length from Vörösmarty et al. (2000a). Details on the river volume calculation are available in Online Resource 1. Lake and reservoir volumes were taken from Green et al. (2004) and the International Commission on Large Dams (1984, 1988), respectively. For application of these data to fate factor calculation, the volume of cells in large lakes needed to be adjusted in the $0.5^{\circ} \times 0.5^{\circ}$ data set to correct for a discrepancy concerning low flows of edge lake cells, as the data set assigned the flow in such edge cells to the centerline of the water body. In the model presented in this manuscript, the volume of edge lake cells has been grouped with the volume of the centerline cells to ensure consistency between the flows and volumes of lake grid cells (Online Resource 1).

\subsubsection{Retention}

The phosphorus retention rate is governed by two main processes: the uptake of phosphorus by biomass and its adsorption to suspended solids and their subsequent physical settling (Hejzlar et al. 2009). The overall retention rate in a grid cell $\left(k_{\text {ret }, j}\right.$, day $\left.^{-1}\right)$ is the volume-weighted average of the removal rates in the separate water bodies $\left(k_{\mathrm{ret}, \mathrm{wb}, j}\right.$, day $\left.^{-1}\right)$, as shown in Eq. 8. These removal rates were taken from the inland nutrient United States fate model SPARROW (Alexander et al. 2004), in which these rates and other input variables are calibrated to predict phosphorus loads in individual streams. Though parameters from SPARROW are derived for the US, this model's calibration includes a wide diversity of streams, lake and climatic conditions that are also found in other continents. Thus, this is the most globally representative approach currently available. However, care must be taken when applying the model to environments that are not predominant in the US, such as tropical ecosystems.

$k_{\mathrm{ret}, j}=\sum_{\mathrm{wb}} \frac{V_{\mathrm{wb}, j}}{V_{\mathrm{tot}, j}} \cdot k_{\mathrm{ret}, \mathrm{wb}, j}$

In Eq. 8, $V_{\mathrm{wb}, j}$ and $V_{\mathrm{tot}, j}$ (both in $\mathrm{km}^{3}$ ) are the total volume of the water body class (the subscript "wb" indicates either river, lake or reservoir class) and the total water volume in grid cell $j$, respectively. This fraction is a volume weighting factor that reflects the fraction of the time the phosphorus resides in the water body of focus relative to its total persistence in that grid cell. The calculation of $k_{\mathrm{ret}, j}$ is explained further in Online Resource 1.

\subsubsection{Water use}

Phosphorus is removed from the water in a grid cell when water is used for domestic, industrial and agricultural purposes. After its use, the water is eventually returned to the freshwater system, but the phosphorus may be retained. The water used for agricultural purposes was assumed to be used for irrigation, in which water is cycled through the soil, which retains a certain fraction of the phosphorus. When water is used for industrial and domestic purposes, a fraction of the phosphorus can be removed through sewage treatment. Global data on phosphorus removal efficiencies of sewage treatment plants are lacking; since applying the same removal efficiency globally cannot be justified, this process was not modeled.

The total amount of withdrawn water can be defined relative to the discharge through $f_{\mathrm{WTA}}$ (dimensionless) (Vörösmarty et al. 2000c), so that the removal rate due to water use $k_{\text {use }, j}\left(\right.$ day $\left.^{-1}\right)$ may be expressed relative to the removal rate by advection, $k_{\mathrm{adv}, j}\left(\mathrm{day}^{-1}\right)$. Because water can be used multiple times, $f_{\mathrm{WTA}}$ can exceed 1 . When the water use was limited by the supply, $f_{\mathrm{WTA}, j}$ was set to 500 , the maximum of the rest of the dataset. Because sewage treatment is not modeled, phosphorus is not removed from water used for domestic and industrial purposes. This is reflected by the term $\left(1-f_{\text {DITW }, j}\right)$, in which $f_{\text {DITW }}$ (dimensionless) is the share of the total water use that is used for domestic and industrial purposes (Vörösmarty et al. 2005). The transport back to the freshwater system depends on the fraction of total phosphorus emissions transferred from soil to fresh water $\left(f_{\text {soil }, j}\right.$, dimensionless $)$.

$k_{\mathrm{use}, j}=f_{\mathrm{WTA}, j} \cdot\left(1-f_{\mathrm{DITW}, j}\right) \cdot k_{\mathrm{adv}, j} \cdot\left(1-f_{\mathrm{soil}, j}\right)$ 
In Eq. $9, f_{\text {soil }}$ is the sum of the fractions of total phosphorus emission to soil transferred to freshwater in the following forms: dissolved inorganic phosphorus $\left(f_{\mathrm{DIP}}\right)$, dissolved organic phosphorus $\left(f_{\mathrm{DOP}}\right)$ and particulate phosphorus $\left(f_{\mathrm{PP}}\right) . f_{\mathrm{DIP}}$ and $f_{\mathrm{DOP}}$ were calculated with relationships from Mayorga et al. (2010), which are runoff-based regressions for these transfer fractions. Maps of the resulting transfer fractions are available as Figs. 2.1 and 2.2 of Online Resource 1 . The transfer fraction of particulate phosphorus from agricultural soils to freshwater was not derived due to lack of data coverage outside of Europe. More details on the calculation and results of the transfer fractions are available as Online Resource 1.

\subsection{Aggregation of fate factors}

The cumulative fate factors can be directly applied when the location of the phosphorus emission is known at a resolution of $0.5^{\circ} \times 0.5^{\circ}$. However, in applications such as LCA, it is currently not possible or feasible to specify the location of emissions at such a high resolution. Therefore, fate factors should be defined for larger areas, such as archetypical situations or political units. Archetypes provide a useful distinction by which to categorize and group grid cells in physically meaningful ways, while political boundaries are often useful, e.g., to the LCA practitioner.

Aggregation over larger areas can be done by emissionweighted averaging of the fate factors, as shown in Eq. 10:

$\mathrm{FF}_{\text {region }}^{\text {average }}=\frac{1}{\sum_{l} E_{l}} \cdot \sum_{l} \mathrm{FF}_{l} \cdot E_{l}$

The regional average $\left(\mathrm{FF}_{\text {region }}^{\text {average }}\right.$, days $)$ is calculated over all grid cells with a nonzero fate factor in a region. $\mathrm{E}_{1}$ is the emission of the region in grid cell $l\left(\mathrm{~kg}^{\mathrm{day}}{ }^{-1}\right)$. Due to limited availability of freshwater phosphorus emission data, $0.5^{\circ} \times 0.5^{\circ}$ gridded population estimates taken from CIESIN et al. (2005) were used as a proxy for point emissions to freshwater. Because point emissions to freshwater are mainly related to human sewage water, population is a good proxy (Wegener Sleeswijk et al. 2008).

An archetypical distinction can be made between emission locations based on the presence of large water bodies downstream. Without large water bodies, there is often a relatively rapid transfer of phosphorus to the ocean. The choice of archetypes can be based on the cumulative distribution of the fate factors (Fig. 3.1 of Online Resource A1). This distribution is the sum of the individual distributions of the two archetypes, so that an inflection point in the cumulative distribution indicates a demarcation between one archetype and another.

\section{Results}

\subsection{Fate factors and aggregation}

The cumulative fate factors for phosphorus emissions to freshwater, $\mathrm{FF}_{i}$, are shown in Fig. 2, available online in color. These represent the cumulative persistence of the phosphorus in the freshwater environment from the point of emission to the ocean. Note that one fifth of all grid cells have a discharge of zero; these are arid, and evaporation exceeds precipitation on a yearly basis. In the model, this implies that no water bodies are present in these grid cells, and $\mathrm{FF}_{i}$ is not applicable. The phosphorus emitted in a non-arid grid cell that is surrounded by arid grid cells (such as in central Australia), is transported to the arid grid cell as defined by the river network. In those cases, $\mathrm{FF}_{\mathrm{i}}$ represents the cumulative persistence from its emission location to an arid grid cell. $\mathrm{FF}_{i}$ exhibits considerable variability: the 5 th and 95 th percentiles of the $\mathrm{FF}_{\mathrm{i}}$ in non-arid areas are 0.8 and 310 days, respectively. The lower values are found in the coastal areas, where phosphorus is quickly transported to the oceans. The higher values are found in areas upstream of large lakes or reservoirs, where the persistence of the phosphorus is high.
Fig. 2 Cumulative fate factors for phosphorus emissions to freshwater $\left(\mathrm{FF}_{i}\right.$, in days) on half-degree resolution

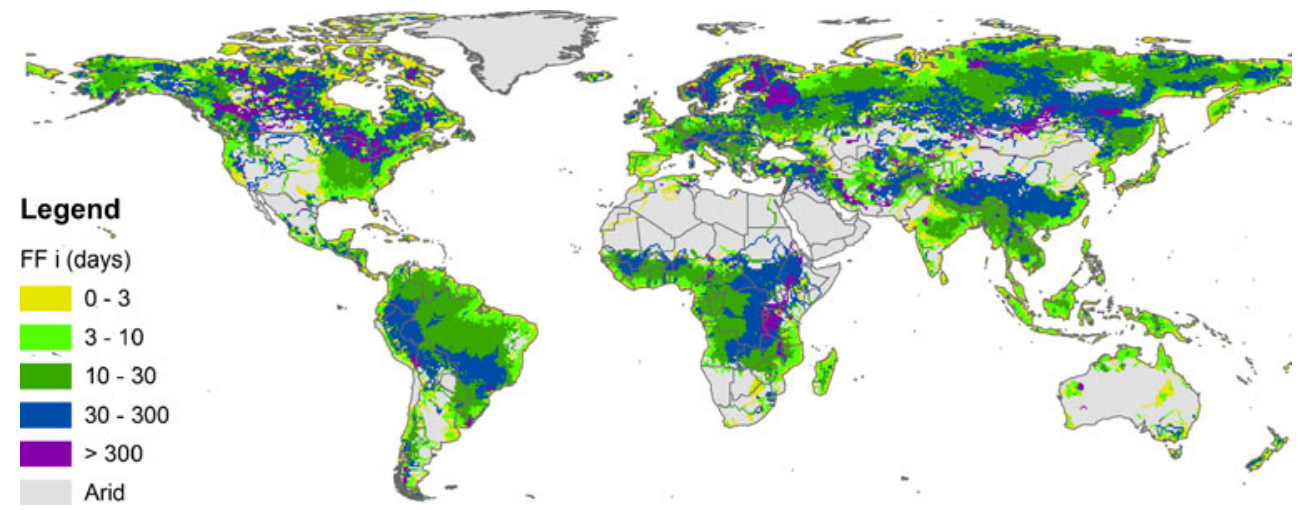




\subsection{Archetypes for phosphorus persistence}

An inflection point in the ranked cumulative fate factors occurs around 30 days (see Fig. 3.1 of Online Resource 1); this value was selected to differentiate between two archetypes. The distinction can be interpreted as differentiating between emissions located upstream of large lakes and reservoirs and those located downstream. This is reflected in the classification of the fate factors in Fig. 2: darker grays (in color, blue and purple) reflect the emission locations upstream of large water bodies, with a $\mathrm{FF}_{\mathrm{i}}$ exceeding 30 days; lighter grays (in color, yellow and green) reflect the emission locations downstream of large water bodies, with a lower $\mathrm{FF}_{i}$. The $\mathrm{FF}_{\text {region }}^{\text {average }}$ of these two archetypes are calculated according to Eq. 10, yielding averages of 610 days for locations upstream and 5.6 days for locations downstream of large water bodies.

\subsection{Regional averages for phosphorus fate}

The country averages for cumulative fate factors are presented in Fig. 3. A table of the country and of the continent average cumulative fate factors, including data on spatial variability, is available in Online Resource 2. Countries on the Arabian Peninsula are arid and thus have no fate factor. The extent of spatial variability is related to the size of the country and to the variety of hydrologic conditions in the country; small countries with a size of 1 grid cell exhibit no spatial variability, while larger countries tend toward the opposite (e.g., Russia has a coefficient of variation of 8.2). Out of 168 countries, two countries have fate factors lower than 1 day and 21 greater than 1 year. At the continental level, averages vary between 4.8 days for Oceania and 474 days for Africa, with a world average of 130 days.

\subsection{Dominant phosphorus removal process}

The influence of the separate removal processes described in the Methods section was determined by calculating the net removal rate for each process for every grid cell. Details on the calculation are given in Online Resource 1. For $67.5 \%$ of the non-arid grid cells, the largest net removal process is advection. Retention is the most important process for $27.6 \%$ of the grid cells. Most of the grid cells where retention is dominant are located in regions upstream of large water bodies with a high residence time of water, i.e., the North American and African Great Lakes, areas of Northern Canada, and around the Finnish and West Russian Lakes. Water use is the dominant removal process for the remainder of the grid cells $(4.9 \%)$. These factors are found in cells located around arid areas like the central United States, central Australia and central Asia. The spatial distribution of dominant processes is shown in Fig. 4. The removal mechanisms and their respective consequences on fate factors are further detailed and discussed in Fig. 3.2 of Online Resource 1.

\section{Discussion}

After comparing the current fate factor model with other nutrient fate models, several sources of uncertainty in the fate factor calculations are presented. Subsequently, possible advances in the impact characterization of freshwater phosphorus are addressed.

\subsection{Comparison with other models}

This model is the first to derive fate factors for phosphorus at the global scale at a half-degree resolution. This development, however, does not facilitate comparison to existing models. The NEWS models (Mayorga et al. 2010), which served as a conceptual basis of the current model, were aimed at estimating nutrient exports through rivers to the ocean, and therefore do not focus on the inland fate of nutrients. These models do take advective transport into account by employing the same river network; furthermore, retention and water use are both modeled as removal processes. SPARROW does focus on the
Fig. 3 Population-weighted country averages of the cumulative fate factors for phosphorus emissions to freshwater
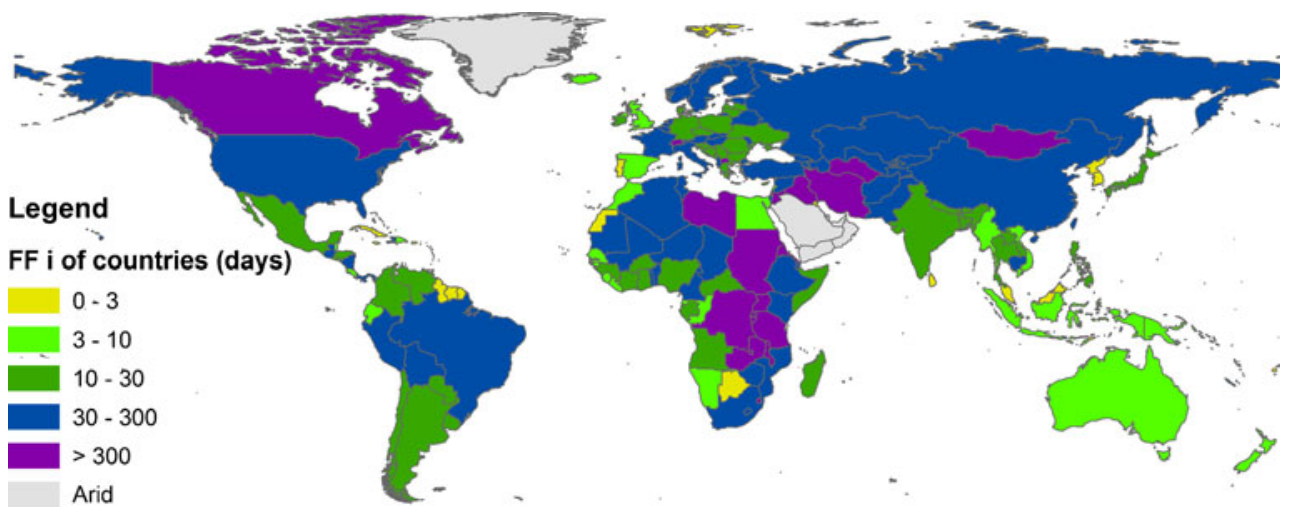
Fig. 4 Spatial distribution of dominant processes for all cumulative fate factors (largest net removal rate)
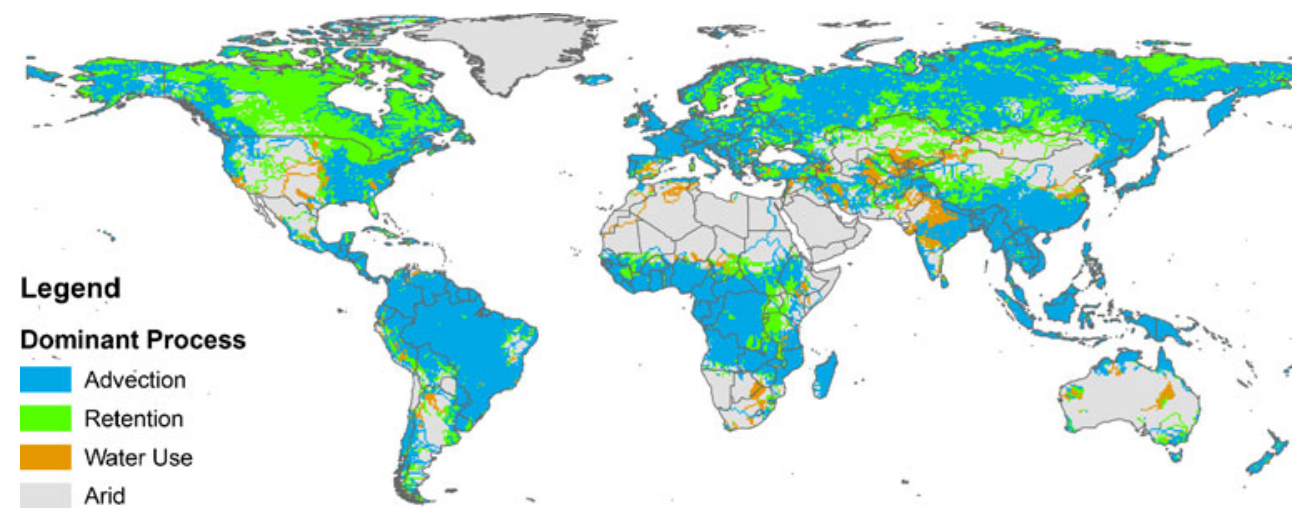

inland nutrient fate but models freshwater nutrient yield of individual streams at the scale of the US, based on data from the US Geological Survey (Alexander et al. 2004). SPARROW uses a different river network and disregards water use. A substantial component of both models is dedicated to estimating emissions, while emissions would serve as an input in the LCIA. Therefore, fate factors cannot be extracted from these models. TRACI does not model the fate of phosphorus, assuming $100 \%$ of phosphorus emissions will reach ecosystems sensitive to $\mathrm{P}$ (Norris 2003).

Struijs et al. (2011) provided fate factors for phosphorus emissions to European freshwater by applying the nutrient fate model CARMEN, to which this manuscript's model results for Europe can be compared. CARMEN models the advective transport of phosphorus on a high resolution $\left(1 / 6^{\circ} \times 1 / 6^{\circ}\right.$, with 124,320 grid cells covering Europe), though it does not include retention and water use as removal processes. In Struijs et al. (2011), partial fate factors for phosphorus sewage (i.e., point) emissions to freshwater in all European countries were derived. Summation of these partial fate factors results in a European fate factor of 111 days. This fate factor is approximately three times larger than the current model's European average of 40 days. A large portion of this difference is explained by the inclusion of retention and water use as removal processes, because the fate factor increases tenfold when these processes are excluded. Remaining differences may be related to the different spatial coverage of the models or the averaging method.

\subsection{Uncertainties}

First, when summing the volume contributions of the three types of water bodies, which are relevant in the calculation of advection, retention and water use, the volume data of a water body should apply only to the grid cell of focus. For river and lake volumes, this is carried out. Reservoirs, however, often have a long shape stretched over multiple grid cells and multiple inflow locations in different grid cells, but their volume data is located in one grid cell (where the dam is located). This input dataset limitation results in an overestimation of the fate factors located between the beginning and the end of the reservoir. Any redistribution of the reservoir volume over upstream grid cells would introduce even more uncertainty and therefore has not been performed.

Second, due to lack of global data on sewage treatment efficiencies, sewage treatment is not implemented in the calculation of the removal rate by water use, $k_{\text {use }}$. In the future, in order to include sewage treatment in the model, efficiencies of sewage treatment for phosphorus could be derived in a manner similar to that employed by Bouwman et al. (2005) for nitrogen. This approach calculated the average sewage treatment efficiency from data on efficiencies of several sewage treatment plant types and their prevalence within countries. If sewage treatment were included, all fate factors would decrease in areas where sewage treatment is present and water use has a non-negligible impact on the cumulative fate factor.

Third, a closed water cycle is assumed in the calculation of $k_{\text {use. }}$ In heavily irrigated areas, however, the evaporation of water during the irrigation process may result in additional retention of phosphorus in the soil and a reduction of the discharge, affecting both $k_{\text {use }}$ and $k_{\text {adv }}$. Additional research is needed to incorporate these effects in a quantitative way.

Fourth, the transfer fraction from agricultural soils to freshwater, relevant for $k_{\text {use }}$, does not include contribution of particulate phosphorus to the transfer fraction. It was possible to calculate $f_{\text {soil }}$, including particulate phosphorus, for European watersheds, by using the relation between phosphorus emissions to soil and the transport of phosphorus to freshwater from Beusen et al. (1995). Details of this calculation are given in Online Resource 1 and a map of the transfer fractions is shown in Fig. 4.1 of Online Resource 1. With the inclusion of $f_{\mathrm{PP}}$, the $f_{\text {soil }}$ increase is $10 \%$ or less for Northern and Central Europe. For Southern Europe and the Norwegian coast, $f_{\text {soil }}$ can be several times (typically two) higher due to higher erosion rates. To understand the effect of the potential increase of $f_{\text {soil }}, \mathrm{FF}_{i}$ was computed with an 
estimated $f_{\text {tot }}$ twice larger than the original $f_{\text {soil }}$. We found that the $\mathrm{FF}_{i}$ increases by a maximum of $0.7 \%$. It can be concluded that the influence of the underestimation of $f_{\text {soil }}$ on $k_{\text {use }}$ is relatively small.

\subsection{Fate factors for other phosphorus emissions}

Once improved data make it possible to include particulate phosphorus in the transfer fraction from soil to water $\left(f_{\text {soil }}\right)$ on a global scale and with a half-degree resolution, fate factors can be derived for phosphorus emissions to (agricultural) soils. In order to do so, the fate factors for emissions to freshwater $\left(\mathrm{FF}_{i}\right)$ need to be multiplied with the improved $f_{\text {soil }}$. Further research on improving this transfer fraction is important, because agricultural emissions to soil contribute strongly to the increased phosphorus concentrations in freshwater. With this addition, it will be possible to provide weighted averages based not only on point source emissions, as in this paper, but also on agriculture production based emissions, which have a different global distribution.

\subsection{Aggregation of fate factors}

By focusing on physically based differences in the data, the use of archetypes preserves the differentiation among the fate factors in a meaningful way. In this case, the two archetypes are grid cells upstream and downstream of large water bodies. Aggregation according to continents and countries has less physical meaning and introduces uncertainty through using population as an emission proxy, but provides LCA practitioners with fate factors that are easier to relate to inventory data. (There is thus a trade-off between differentiation and practicability.) Since archetypical groupings in other impact categories, such as freshwater ecotoxicity, may be strongly influenced by the cumulative residence time of water, it would be practical to choose the cumulative residence time of water instead of the phosphorus itself. Choosing identical archetypical definitions would create the same regions of archetypes across impact categories, reducing spatial data demands for the LCA practitioner while providing meaningful distinctions between emission locations.

\subsection{Characterization factors}

The presented fate factors for phosphorus emissions to freshwater can be multiplied with effect factors for phosphorus emissions to freshwater to yield characterization factors for freshwater eutrophication. Struijs et al. (2011) derived concentration dependent effect factors, with a typical value of $200 \mathrm{PDF} \mathrm{m} \mathrm{kg}^{-1}$. This results in a 5th and 95th percentiles for the characterization factors of 160 and $6.2 \times 0^{4}$ days PDF $\mathrm{m}^{3} \mathrm{~kg}^{-1}$, respectively. This information can be used in endpoint assessments to aggregate various stressors to an overall ecosystem quality damage score. The effect factor could be improved by differentiating between effects in rivers and lake, e.g., as done by Payet (2006). Furthermore, effect factors from Payet scale with trophic state (e.g., oligotrophic vs. mesotrophic), implying ecosystem effects at all levels of $\mathrm{P}$ concentration. The water body specific effect factors could then be applied to the cumulative persistence of the phosphorus in the corresponding water body. Further research is necessary to fully distinguish lake and river contributions to the fate factor, and to synthesize multiple approaches to the effect factor.

\section{Conclusions}

The fate factors for freshwater eutrophication presented in this paper enable a significant increase in spatial extent and resolution for LCIA. Local hydrological properties have the largest impact on these fate factors. Characterization factors derived from these fate factors make it possible to consistently account for freshwater eutrophication impacts of globalized production. Previously, characterization of phosphorus emissions relied on factors developed in the European or North American context, regardless of the location of the emissions. A spatially explicit and consistent global approach is crucial in the case of complex products whose components are manufactured in several locations, countries, or continents.

Acknowledgements This research was partly funded by the European Commission under the 7 th framework program on environment, ENV.2009.3.3.2.1: LC-IMPACT-Improved Life Cycle Impact Assessment methods (LCIA) for better sustainability assessment of technologies, grant agreement 243827 . Funding was also provided by the Dairy Research Institute as part of the United State Comprehensive Milk Life Cycle Assessment, as well as by the Sustainability Consortium (TSC).

Open Access This article is distributed under the terms of the Creative Commons Attribution License which permits any use, distribution, and reproduction in any medium, provided the original author(s) and the source are credited.

\section{References}

Alexander RB, Smith RA, Schwarz GE (2004) Estimates of diffuse phosphorus sources in surface waters of the United States using a spatially referenced watershed model. Water Sci Technol 49(3):1-10

Bennet EM, Carpenter SR, Caraco NF (2001) Human impact on erodable phosphorus and eutrophication: A global perspective. Bioscience 51(3):227-234

Beusen A, Klepper O, Meinardi CR (1995) Modelling the flow of nitrogen and phosphorus in europe: from loads to coastal seas. Water Sci Technol 31(8):141-145

Bouwman AF, Van Drecht G, Knoop JM, Beusen AHW, Meinardi CR (2005) Exploring changes in river nitrogen export to the world's oceans. Global Biogeochem Cycles 19:GB1002 
Carpenter SR, Caraco NF, Correl DL, Howarth RW, Sharpley AN, Smith VH (1998) Nonpoint polution of surface water with phosphorus and nitrogen. Ecol Appl 8(3):559-568

CIESIN, Center for International Earth Science Information Network Columbia University, United Nations Food and Agriculture Programme (FAO), Centro Internacional de Agricultura Tropical (CIAT) (2005) Gridded Population of the World: Future Estimates (GPWFE). Socioeconomic Data and Applications Center (SEDAC), Columbia University, Palisades, NY

Fekete BM, Vörösmarty CJ, Grabs W (2000) Global, composite runoff fields based on observed river discharge and simulated water balances. Institute for Earth, Oceans, and Space, University of New Hampshire, Durham, NH

Fekete BM, Vörösmarty CJ, Grabs W (2002) High-resolution fields of global runoff combining observed river discharge and simulated balances. Global Biogeochem Cycles 16 (3):1042-1044

Green PA, Vörösmarty CJ, Meybeck M, Galloway JN, Peterson BJ, Boyer EW (2004) Pre-industrial and contemporary fluxes of nitrogen through rivers: a global assessment based on typology. Biogeochemistry 68:71-105

Harrison JA, Seitzinger SP, Bouwman AF, Caraco NF, Beusen AHW, Vörösmarty CJ (2005) Dissolved inorganic phosphorus export to the coastal zone: results from a spatially explicit, global model. Global Biogeochem Cycles 19:GB4S03

Hejzlar J, Anthony S, Arheimer B, Behrendt H, Bouroui F, Grizzetti B, Groenendijk P, Leuken MHJL, Johnsson H, Lo Porto A, Kronvang B, Panagopulos Y, Siderius C, Silgram M, Venohr M, Zaloudník J (2009) Nitrogen and phosphorus retention in surface water: an intercomparison of predictions by catchment models of different complexity. J Environ Monit 11:584-593

Huijbregts MAJ, Seppälä J (2000) Towards region-specific, European fate factors for airborne nitrogen compounds causing aquatic eutrophication. Int J Life Cycle Assess 5(2):65-67

Humbert S, Manneh R, Shaked S, Wannaz C, Horvath A, Deschênes L, Jolliet O, Margni M (2009) Assessing regional intake fractions in North America. Sci Tot Environ 407(17):4812-4820

International Commission on Large Dams $(1984,1988)$ World Register of Dams. http://www.icold-cigb.net/

Mayorga E, Seitzinger S, Harrison JA, Dumont E, Beusen AHW, Bouwman AF, Fekete BM, Kroeze C, Van Drecht G (2010) Global Nutrient Export from WaterSheds (NEWS 2): model development and implementation. Environ Modell Softw 25:837-853

MEA (2005) Ecosystems and human well-being. Millennium Ecosystem Assessment, Island Press, Washington, DC

Norris GA (2003) Impact characterization in the tool for the reduction and assessment of chemical and other environmental impacts. Methods for acidification, eutrophication and ozone formation. $\mathrm{J}$ Ind Ecol 4(3-4):79-101

NRC (1992) Restoration of aquatic ecosystems: science, technology, and public policy. National Research Council, Washington, DC

OECD (1982) Eutrophication of waters: monitoring, assessment and control. Organization for Economic Cooperation and Development, Paris

Payet J (2006) 3-Quantifying effects of eutrophication in freshwater ecosystems. In: Report describing a method for the quantification of impacts on aquatic freshwater ecosystems resulting from different stressors (e.g. toxic substances, eutrophication, etc.). EPFL, Lausanne, pp 13-21

Pennington DW, Potting J, Finnveden G, Lindeijer E, Jolliet O, Rydberg T, Rebitzer G (2004) Life cycle assessment: Part 2. Current assessment practice. Environ Int 30:721-739

Potting J, Beusen A, Øllgaard H, Hansen OC, De Haan B, Hauschild M (2005) Aquatic Eutrophication. In: Hauschild MZ, Potting J (eds) Spatial differentiation in Life Cycle Impact AssessmentThe EDIP2003 Methodology, vol 80, Institute of Product Development. Technical University of Denmark, Lyngby, pp 69-88
Potting J, Blok K (1994) Spatial aspects of life-cycle impact assessment. In: Udo de Haes HA, Jensen AA, Klöpffer W, Lindfors L-G (eds) Integrating impact assessment into LCA. Society of Environmental Toxicology \& Chemistry, Brussels, pp 91-98

Potting J, Blok K (1995) Life-cycle assessment of four types of floor covering. J Cleaner Prod 3(4):201-213

Potting J, Hauschild MZ (2006) Spatial differentiation in life cycle impact assessment - a decade of method development to increase the environmental realism of LCIA. Int J Life Cycle Assess 11:11-13

Potting J, Schöpp W, Blok K, Hauschild MZ (1998) Site-dependent lifecycle impact assessment of acidification. J Indust Ecol 2(2):63-87

Rosenbaum R, Margni M, Jolliet O (2007) A flexible matrix algebra framework for the multimedia multipathway modeling of emissions to impacts. Environ Int 33:624-634

Schindler DW (1977) Evolution of phosphorus limitation in lakes. Science 195(4275):260-262

Schindler DW (2006) Recent advances in the understanding and management of eutrophication. Limnol Oceanogr 21(1):356-363

Seitzinger SP, Harrison JA, Dumont E, Beusen AHW, Bouwman AF (2005) Sources and delivery of carbon, nitrogen, and phosphorous to the coastal zone. Global Biogeochem Cycles 19:GB4S01

Smith VH (2003) Eutrophication of Freshwater and Coastal Marine Ecosystems. Environ Sci Pollut Res 10(2):126-139

Sterner RW (2008) On the phosphorus limitation paradigm for lakes. Int Rev Hydrobiol 93(4-5):433-445

Struijs J, Beusen A, Van Jaarsveld H, Huijbregts MAJ (2009) Eutrophication. In: Goedkoop M, Heijungs R, Huijbregts M, De Schryver A, Struijs J, van Zelm R (eds) ReCiPe 2008, A Life Cycle Impact Assessment method which comprises harmonised category indicators at the midpoint and the endpoint level. Report I Characterization. Ministry of Housing, Spatial Planning and the Environment (VROM) Den Haag, pp 60-67

Struijs J, De Zwart D, Beusen A, Huijbregts MHJ (2011) Characterization factors for inland water eutrophication at the damage level in life cycle impact assessment. Int J Life Cycle Assess 16(1):59-64

Tilman D, Fargione J, Wolff B, D'Antonio C, Dobson A, Howarth R, Schindler D, Schlesinger WH, Simberloff D, Swackhamer D (2001) Forecasting agriculturally driven global environmental change. Science 292(5515):281-284

Toffoleto L, Bulle C, Godin J, Reid C, Deschênes L (2006) LUCAS - a new LCIA method used for a Canadian-specific context. Int J Life Cycle Assess 12(2):93-102

Vörösmarty CJ, Fekete BM, Meybeck M, Lammers R (2000a) Geomorphometric attributes of the global system of rivers at 30-minute spatial resolution (STN-30). J Hydrol 237:17-39

Vörösmarty CJ, Fekete BM, Meybeck M, Lammers R (2000b) Global system of rivers: its role in organizing continental land mass and defining land-to-ocean linkages. Global Biogeochem Cycles 14:599-621

Vörösmarty CJ, Green PA, Salisbury J, Lammers RB (2000c) Global water resources: vulnerability from climate change and population growth. Science 289:284-288

Vörösmarty CJ, Lévêque C, Revenga C. (2005) Fresh water. In: Hassan R, Scholes R, Ash N (eds) Ecosystems and human well-being: current state and trends, vol 1. Millenium Ecosystem Assessment Series. Island Press, Washington, DC, USA

Wegener Sleeswijk A, van Oers LFCM, Guinée JB, Struis J, Huijbregts MAJ (2008) Normalisation in product life cycle assessment: An LCA of the global and European economic systems in the year 2000. Sci Total Environ 390:227-240

Withers PJA, Jarvie HP (2008) Delivery and cycling of phosphorus in rivers: a review. Sci Total Environ 400:379-395

Wollheim WM, Vörösmarty CJ, Peterson BJ, Seitzinger SP, Hopkinson CS (2006) Relationship between river size and nutrient removal. Geophys Res Lett 33:L06410 